\title{
Contested energy futures: Shaping renewable energy narratives in
}

\section{Australia}

\section{Introduction}

Climate change is both a major global problem and a major area of contestation. This is because its redress challenges established economic patterns and interests and the government business relations cultures that intersect those interests. Energy production and use is both a critical component of the socio-economic landscape as well as a key driver of the climate problem. With a significant proportion of climate change deriving from the predominant use of fossil fuels to generate this energy, any serious response to the climate problem will require changes to this prevailing energy landscape. This is easier said than done; even in the face of the potential of alternative, and less greenhouse intensive, energies to reduce global warming. Through its direct link to a country's economic fabric, a country's energy profile is a significant determinant of its energy politics, and most countries are challenged in important ways by the climate and energy dilemma. Australia is no different. But it is in energy intensive economies such as Australia, where the emissions load reduction poses significant restructuring challenges to the energy status quo, that the energy politics are particularly acute and the narrative contests that negotiate them particularly intense. The Australian renewable energy story thus reveals some important observations about the broader politics of climate policy and the discursive strategies deployed to shape it.

Australia is endowed with abundant mineral resource wealth. Its fossil fuel assets form the basis of its comparative advantage in relatively cheap electricity 
generation, both for domestic consumption and as an investment incentive. Australia is the world's largest coal exporter and the fourth largest coal producer. It has large reserves of natural gas (sixth largest holder in Asia) and is the fifth largest exporter of Liquified Natural Gas (LNG) (EIA, 2010). While it has no nuclear power plants, it holds 23 per cent of global uranium reserves (World Nuclear Association, 2011). It is currently expanding its growing access to coal seam gas (approximately 50 per cent less greenhouse gas intensive than conventional coal), with several large projects already under way. ${ }^{1}$ Altogether fossil fuels supply approximately 95 per cent of Australia's stationary energy with almost 85 per cent of electricity generation produced by coal.

The other face of this energy abundance is Australia's contribution to global warming. Australia's emissions intensive energy profile renders it the highest global per capita emitter of greenhouse gases and a business-as-usual approach to energy policy will see these emissions increase significantly in the foreseeable future (see Parker and Blodgett, 2008). Despite its resource wealth, Australia confronts some significant energy challenges. The National Energy Security Assessment (2009) finds that these challenges are those posed by increasing energy demand and accelerating climate change. The challenges are threefold: first, to meet its accelerating energy demands reliably and at affordable prices; second, to simultaneously contain negative environmental effects; and third, to reposition itself in a changing global energy market (NESA, 2009). These pressures are complicated by Australia's geography which, despite great geographical contrasts and weather extremes, is essentially a hot and dry continent particularly vulnerable to climate change.

1. Coal seam developments have not proceeded unproblematically, however, and opposition to the rapid expansion of coal seam mining projects is accelerating. Many of these projects, especially in Queensland, are highly contested by local communities not convinced that they will not contaminate underground water sources and impact negatively on the future of farming endeavours (see ABC, 2011). 
While of a different type and scale, Australia also has abundant renewable energy resources. Paradoxically, some of the features that make Australia vulnerable to climate change - such as its hot, sunny conditions - are also features that provide extensive opportunity for potential solar, wind and geothermal developments. With some of these renewable technologies already well advanced, this paper argues that the factors that stymie their more rapid progression are political as much, or even more so, as they are technical. With its mineral wealth a longstanding centrepiece of Australia's economic strength, it is no surprise that the mining sector - and energy intensive industries that rely on Australia's low cost electricity - occupy an influential position in Australia's political economy, accommodated, historically, by a mutually supportive government-business relations culture. The renewable energy sector hence confronts considerable obstacles in its attempts to win itself a place at Australia's energy table. With increasing pressures to consider the sustainability of its energy future, and with a well established energy sector disinclined to forgo its advantages, the Australian energy policy stakes are high. A winning narrative goes some way towards managing these stakes.

Discourses and narratives are central to how we interpret and understand the world. An actor's capacity to advance their interests often relies on the effective construction and dissemination of narratives. Since it is often at the level of narratives that energy and climate politics are revealed, this paper examines some of the main narratives through which the conversation about renewable energy in Australia takes place. It contends that these narratives help shape the profile of renewable energy in Australia in important ways, ultimately impacting the renewable energy sector's standing, status and future. It is thus important to identify and interrogate these narratives in order to more adequately consider the contribution that renewable energy 
could make to addressing the climate problem. We label these narratives feasibility ('Pie in the Sky'); security ('Keeping the Lights on'); cost ('Costing the Earth'); and employment ('Jobs Carnage'). Some of the most effective narratives are those that build on important elements of the issue at hand and that intersect the legitimate concerns, and fears, that surround the issue. This reinforces an impression of reasonableness that is important in the issue conversations that take place in democratic polities. This paper's narrative interrogation, however, pays particular attention to counter-narratives that are missing or marginalised from the energy conversation - narrative 'absences' that would more accurately contextualise the prevailing narratives that dominate it. Our focus is Australia, but some of the narrative dynamics revealed have application to the energy politics of other established democracies across the globe, particularly other energy intensive economies (such as the United States) whose politics are shaped by similar forces (see Christoff, 2005, 2010; Curran, 2009).

\section{A Narrative Approach}

The narratives and discourses that frame issues influence how we understand them, and the values we ascribe them. A basic premise of discourse theory is that meaning is socially constructed and that some actors have more capacity to influence this social construction than others. The language and communication that underpins discourses are not neutral processes; instead discourses are 'grounded in the awareness that language profoundly shapes our view of the socio-political world rather than merely mirroring it' (Fischer, 2003, p. 47). For Foucault meaning is constructed through a myriad of 'discursive practices' that inscribe and interpret social behaviours and events (Foucault, 1980). While discourses are mainly associated with language and 
text they also include the social positioning of, and interaction between, actors within the broader social context in which an issue is situated. These practices include the positioning of social actors ('subject positions') within a discourse so that some actors are positioned more influentially than others, and their value positions and hence interpretations are privileged over others (see Hajer, 1995. p. 65). Discourses can thus be understood as "specific ensembles of ideas, concepts and categorization that are produced, reproduced and transformed in a particular set of practices' (Hajer, 1995, p. $45)$.

The capacity to shape the main knowledge claims of discourses so that the interests of some actors are promoted while others are contained thus connotes a considerable exercise of power. As Dryzek puts it, with each discourse resting on 'assumptions, judgements, and contentions that provide the basic terms for analysis, debates, agreements, and disagreements. ... [d]iscourses are bound up with political power' (Dryzek, 2005, p. 9). This helps explain the prevailing contests within the policy making arena for command of the discourses that act to frame particular issues. Discourse analysis thus seeks to uncover the power relations that attach to different discourses, focusing in particular on the power/knowledge dynamic (Foucault, 1980); that is, the 'interaction of power (who or what has dominated the process) and knowledge (what information is privileged and negated by those who have power) (Pettenger, 2007, p. 11)'. The discursive framing of the 'science' of climate change, for example, illustrates well the character and import of these competing narratives (see Jacques et al, 2008; Rogers-Hayden et al., 2011).

Discursive capacity is advanced through the use of 'rationalities', or 'sensemaking', that are often delivered through narratives - the 'coherent' stories that are told about the issue at hand. These rationalities 'frame the sorts of knowledge which 
“count" as valid statements within the policy process' hence assuming 'power through rationalisation' (Stevenson, 2009, p. 514; see also Flyvbjerg, 1998). Discourses thus shape an issue's 'basic terms for analysis', often through the telling of specific stories about it (Dryzek, 2005, p. 17; see also Hajer, 1995, p. 56). As Fischer notes, to 'understand the world around them, most people do not draw on comprehensive discursive systems for their cognition. Instead, they rely on storylines' (Fischer, 2003, p. 86). These storylines provide not only accessible and short hand routes into the consideration of specific issues, but also provide normative criteria, or values, for evaluating the information at hand.

The force of storylines and narratives lies in their capacity to both simplify and organise discourses, helping explain their usefulness in the public policy domain, a domain where complex information has to be rendered digestible for public consumption, as well as presented in a manner that wins desired support. Policy narratives are often strengthened and reinforced by 'discourse coalitions' of actors pursuing similar discursive goals (Hajer, 1995; Hajer, 1993). A focus on the structure of a discourse, the narratives and stories that aid its telling, and the constellation of actors that seek to advance it, can reveal much about its politics - that is, the capacity to present, advance or suppress ideas and interests. Before we turn to the different narratives that underpin this particular Australian story, we briefly outline Australia's current renewable energy profile.

\section{Australia's renewable energy profile}

In 2009 renewable energy supplied 6.5 per cent of electricity generation in Australia. Of this hydro-generation provided 77 per cent; wind 16 per cent; biomass 7.2 per cent; large scale solar PV and solar thermal 0.08 per cent; and wave and geothermal 
currently contributing a very small measure (CEC, 2010). Wind is presently the success story in renewables, with a strong foothold in European countries such as Germany, Denmark and Spain. It is also one of the world's fastest growing industries, with around 20 per cent growth per annum between 1974-2007, as well as, currently, Australia's largest renewable after hydro (Lovegrove, 2008; CEC, 2010). Wind's capacity to produce energy relatively quickly, efficiently and cost effectively is tempered by contention around its reliability, visual amenity, health concerns and siting (Hindmarsh and Mathews, 2008; Toke, 2005). Offshore wind projects are partly geared towards offsetting these problems, although they introduce a number of specific issues of their own (Ladenburg, 2008, 2009; Haggett, 2008; Toke, 2011).

Solar photo-voltaic (pv) panels are particularly well established and well suited small domestic grid connected systems, with solar pv currently generating approximately 1 per cent of Germany's electricity use although this is expected to increase to 25 per cent by 2050 (AAS, 2010, p. 13). Biomass production, particularly useful for rural applications, is also well established. Over 90 per cent of biomass uses similar electricity generation processes to those of coal. The related fermentation process produces ethanol which is increasingly used in Australia (as elsewhere) as a transport fuel. The production of bio-fuels poses a number of concerns worldwide, however particularly the environmental consequences of broad scale clearing to grow suitable crops; the social and economic impacts on food production and distribution; and the logging of old growth forests (Pimentel et al., 2009; Altieri, 2009).

Solar thermal with storage is considered to have the most large-scale potential, including the production of base-load power. It is judged to work 'an absolute treat', has been successfully deployed in Arizona and Nevada (Lovegrove, 2008), and is 
currently in deployment in Spain (Brait and Ewbank, 2010). A recent Australian study, observed that the sun's 'energy falling on Australia in one day is equal to half the total annual energy required by the whole world. To power all of Australia's energy needs would require only 0.3 per cent of the land surface to be devoted to solar power generation' (AAS, 2010, p. 7). Others have calculated that 'an area measuring $35 \mathrm{~km}$ by $35 \mathrm{~km}$ located in a region with high solar radiance and low cloud cover could generate enough electricity to meet all of Australia's current electricity generation if covered with a solar thermal electricity generation system' (See Buckman and Diesendorf, 2009, p. 13). This calculation, however, does not include infrastructure, distribution and transport costs to major population centres.

Among Australia's renewable resource endowments is its geothermal capacity, or 'hot rocks'. Several sites of geothermal activity have already been identified as suitable in NSW, Queensland and the Northern Territory. The technology is relatively advanced, and research and development has moved to the demonstration phase. While still very small scale, the United Nations Environment Program estimates that Australia will have approximately 7 per cent of geothermal power by 2030 (AAS, 2010, p. 17). As with solar thermal, infrastructure development and transport costs remain substantial. Wave and tidal power, especially the former, is also promising, enhanced by Australia's abundance of coast line. Scenarios determine that the utilisation of power from ocean energy could provide up to 25 per of Australia's power needs by 2060, with southern Australia having significant 'potential for very high load factors' (AAS, 2010, p. 7). Taken together, these kinds of renewables scenarios have prompted several recent studies to arrive at promising conclusions (See AAS, 2010; Seligman, 2010; Beyond Zero Emissions, 2010). Reflecting shared conclusions, one states that: 
Whether we use pumped hydro, molten salt or hydrogen storage and which mix of wind, solar, wave and geothermal power we use, the conclusion is the same. Given the will, we could supply all our energy needs in a sustainable and mostly renewable way. We could do this at a price we could afford. Possibly the best solution will be a combination of these approaches (Seligman, 2010, p. 107).

\section{Renewable Energy Narratives}

The narratives that frame renewable energy influence the sector's status and its public standing and support - in Australia as elsewhere. We organise these interrelated narratives into four main categories: feasibility, security, cost and jobs and consider each in turn. These narratives have been chosen because of their centrality to the overall structure and culture of advanced capitalist democracies such as Australia. These advanced industrial societies are diverse, complex and multi-layered but most are characterised and shaped by two key interrelated elements: economic growth - the motor of a market economy; and state legitimacy - state and government capacity for maintaining the legal, structural and institutional infrastructure on which market operations, and associated socio-economic relations, depend (Ingham, 2008, pp. 5262; see also Dryzek 2005, 9-10). A country's economic and socio-cultural outlook, and a government's political success, is in turn conditioned by its employment profile; its management of cost and inflationary pressures; the efficiency and effectiveness of its economic and social infrastructure; and its overall capacity to do 'its business' in relative peace and security. Since these factors constitute the central "imperatives, or functions that governments of most contemporary national [democratic] states must fulfil" most policy issues, and the discourses and narratives that frame them, are thus negotiated through the prism of these core elements (Scrase and Ockwell, 2010, p. 2227). 
The potency of a narrative, however, is determined as much by what is absent from its storyline as what is present. Hence this paper's additional analytical focus on narrative 'absences' and their role in shaping the scope and influence of the prevailing narratives. Essentially, a story that castes renewable energy as too unlikely, too costly, too job-destroying and too unreliable competes vigorously to dominate the perception of the renewable energy possibility in energy intensive economy such as Australia. Part of the narrative potency of such an account lies in the unease it triggers over the capacity of such an advanced industrial democracy to address its core socio-economic functions - core funtions that citizens are both familiar with and rely upon, and that in turn invests this narrative account with its 'reasonableness'.

\subsection{Feasibility: 'Pie In The sky'}

Renewable energy, or at least the idea of it, enjoys considerable public support in Australia (Newspoll and CEC, 2009, 2010; Energy Matters, 2009). The tenor and scale of this support is less clear, however. While there is quite widespread support for, and familiarisation with, domestic renewable sources such as subsidised rooftop solar panels and solar hot water, whether this support and familiarisation extends to a more ambitious roll out of renewables is less certain. This uncertainty and knowledge gap presents interested actors with a useful discursive space. Confronted with quite sympathetic public views, the conventional energy sector and its supporters tread cautiously in their public response to renewable energy developments and the public policies designed to advance them. In some ways, those seeking to caste doubt on the feasibility of renewable energy utilise some of the strategies employed by climate 'sceptics'. Some of the latter focus much of their opposition to climate policies on the perceived inadequacy of the science in establishing a clear link between actual climate 
change and humanity's contribution to it, rather than simply denying that some (albeit non-human caused) climate change may be occurring (see Jacques et al., 2008). Similarly renewables 'sceptics' concentrate on casting doubt on renewables' feasibility, capacity and cost - rather than simply dismissing the idea of renewables altogether (see Diesendorf, 2010).

Only the more combative will invoke the feasibility issue derisively, condemning the foolishness of 'replac[ing[ our low cost energy by the pie-in-the-sky new technologies (Moran, 2010). Instead, often in keeping with nominated CSR principles, much of the energy sector pledges their commitment to a 'low carbon future' and 'clean' energy. The Minerals Council of Australia, for example, representing companies that produce over 85 per cent of Australia's annual mineral output, prefaced their 2009 submission to the Renewable Energy (Electricity) Amendment Bill (2008) as their 'contribution to sustainable development and society' (MCA, 2009). In it, they detailed their 'five fundamental concerns' with the proposed expansion of the government's main renewable energy policy: the Mandated Renewable Energy Target (MRET). The concerns they raise echo the key narratives. They claim that the MRET would:

- distort the operation of a well-designed emissions trading scheme [since withdrawn];

- achieve no additional abatement;

- raise electricity costs;

- have a negative effect on jobs in the overall economy;

- exacerbate concerns about reliable and uninterrupted supply of energy [emphasis added]. 
The last three points are revealing. While the concerns listed are specific responses to a specific policy, they nonetheless highlight the issues of cost, jobs, reliability and security. The last point in particular raises what is considered to be one of renewable energy's main feasibility hurdles: its capacity to provide base load power.

The ability to generate stable and continuous base load electricity, from whatever source, is the holy grail of energy security. Base load is defined as continuous power generation - 24 hours a day, 7 days a week - provided by generators that are in continuous operation. It is one of the core energy characteristics of advanced industrial states and it is thus no surprise that this becomes a key focus of most countries' energy conversation and the narratives that frame it. Australia is no different. A widespread perception about renewable energy in this country is that it is not up to the base load task because of its intermittency, unreliability and limited scale. A prominent journalist, reporting on what she claims is wind power's 'whole green con', states that:

The idea of clean green wind power sounds good in theory, but the problem is that wind is intermittent. When it doesn't blow there is no electricity, so you need fossilfuelled power ready on stand-by to provide the base-load electricity at peak times or on still days' (Devine, 2011).

This is reinforced by another media piece which also castes doubt on wind power's, and by implication renewable energy's, feasibility and reliability. Lloyd (2011) concludes this piece with an observation from a landholder resisting the construction of wind turbines in his local area: 
Wind must be the only technology where you can prove inefficiency and people say, 'We'll have to build two of them or three of them or four' ... 'You can't sell anybody any other piece of equipment and say to them, 'We don't know if it is going to work. Sometimes it will work really well, sometimes it won't work at all and other times it will work a bit’.

Two core questions help us interrogate this perception and the base load narrative that underpins it: first, can renewable energy provide base load; and second, does renewable energy need to provide base load to make a significant contribution to the future energy mix? As discussed, some of the most effective discourses are often those that approximate legitimate concerns. In this vein, when speaking at an Australian Academy of Science public lecture in 2009, research scientist John Wright points out that, rather than straying too far from actuality, critics of renewable energy do raise legitimate concerns: there are indeed renewable technologies 'which are always going to be variable'; importantly, however, there are 'certainly ways around that' (AAS, 2009). In answer to the question of whether renewable energy can provide base load, Wright goes on to reference a body of evidence that points to just such a capacity, with the most formidable barriers to the development of renewable base load more likely to be cost and policy commitment than technological feasibility (Wright, 2009).

In an article titled 'The Base Load Fallacy' (Diesendorf, 2010) and another that discusses 'the base load myth' (Mills, 2010), both authors contend that that the 'conventional wisdom' that renewable energy is unable to provide base load is a fallacy or myth that is repeatedly propagated by a range of actors intent on protecting the energy status quo. This 'fallacy' seeks to ensure that 'renewable energy would always have to remain a niche market, rather than achieve its true potential of 
becoming a set of mainstream energy supply technologies with the capacity to supply all of Australia's and indeed the world's electricity' (Diesendorf, 2010, p. 2). Central to the 'confusion' is the understanding of base load, particularly the central notions of 'variability' (to which conventional energy generation sources are also vulnerable); 'intermittency' (distinguishing between, for example, single wind turbines vis-à-vis larger scale wind farms); and 'reliability' (with solar thermal with storage capable of supplying base load 'with the same reliability as coal') (Diesendorf, 2010, pp. 2-3).

Mills (2010) observes that base load output in 'not a fundamental requirement of modern energy production' in any case; rather it is 'a characteristic of certain fossil, geothermal and nuclear plants that are operated continuously to lower their relative capital expenditure versus fuel cost'. More important to securing energy supply 'is the ability to match inflexible sources of power — those that can only generate energy at certain times such as wind — with flexible sources of power those that can generate and store energy such as solar' (Mills, 2010). Recent reports have reinforced renewables potential for base load (see AAS, 2009; Seligman, 2010; Beyond Zero Emissions, 2010).

The second question considers renewable energy's contribution beyond base load. A narrative focus on base load tends to overlook another important element of the renewable energy profile: its capacity to contribute to a diverse and distributed portfolio of energy mixes, one that recognises that different energy forms, including conventional energy, are more suitable in different locations and at different scales. This enables a graduated and transitional renewable contribution to electricity supply while issues of cost, scale and infrastructure are addressed, in particular infrastructure upgrades that better accommodate 'distributed' energy. Distributed energy is defined as 'energy supply and management options close to where the energy is used, and 
includes local generation, end use energy efficiency, and peak load management' (Rutovitz and Dunstan 2009, p. vi). It includes the connection of electricity generators to the distribution rather than the electricity transmission network, and can include the contributions of domestic solar systems and 'gas combined cycle cogeneration', as well as accommodating the additional renewable energy electricity that the revised 20 per cent Mandated Renewable Energy Target will generate in the medium term (Rutovitz and Dunstan 2009, p. 10). An important feasibility, and energy security, issue thus becomes the "smooth transition of renewable energy technologies into the overall energy mix' and a shift away from what some call 'energy class wars' - that is, between 'traditionals' such as fossil fuels or nuclear and renewables (Wright, 2009).

\subsection{Security: 'Keeping the lights on'}

Allied to the feasibility issue is the security narrative. Highlighting the centrality of security to the energy debate, a recent media article in a major national daily reported that: 'Crunch time for electricity supplies across the country is coming, and it's coming as early as 2013-14'; inviting the questions: 'Will the lights go out, and when?' (Hepworth, 2011a). Energy security, fundamental to a country's lifestyle and economic performance, is a powerful narrative, with Australia's long-standing experience of affordable and reliable electricity reinforcing its potency. Energy security is usually understood as the capacity of a country to ensure the adequate, reliable and affordable supply of energy in order to meet its social and economic objectives. Adequacy refers to the ability to provide sufficient energy to undertake a country's designated economic and social activities; reliability seeks continuity of supply with minimal disruptions; and affordability signals the provision of energy at a 
price that advances economic activity and is accessible to most households (NESA, 2009 , p. 5). The same media article found renewable energy problematic on all three counts, concluding that renewables offer little in the way of energy security and reliability, hence rendering them limited in their capacity to help address Australia's current energy 'crises'. Indeed, the article concludes that there remains 'serious questions about the alternative generators' impact on the reliability of the power system' because of renewables' intermittency and hence lack of security (Hepworth, 2011a). Indeed, renewable energy, particularly wind power, 'promises so much and delivers so little' (Devine 2011).

These 'crises' refer to the fact that, despite Australia's plentiful energy, it nonetheless faces a range of energy security challenges. The Minister for Energy recently observed that in order to meet the accelerated growth in demand, Australia's electricity generation was expected to grow by nearly 50 per cent by 2030 (Ferguson, 2010). This reinforces the National Energy Security Assessment (2009) findings that Australia's main energy pressures are those posed by increasing demand and accelerating climate change. These pressures include facilitating timely and appropriately sized investment in the energy sector; the restructuring required for a lower carbon economy; providing internationally competitive frameworks for Australian industry; and continuing to deliver reliable, adequate and affordable energy to Australian households (NESA, 2009, p. 1). The Assessment concludes that levels of electricity generation security to 2025 will be moderate. Despite Australia's well established electricity markets, it remains vulnerable to 'supply-side shocks' including uncertainty about domestic and global climate policies (NESA, 2009, p. 21).

To avoid these supply shocks Australia's energy security relies on a significant boost of power generation in the medium and long term. The uncertain 
political and economic climate, however, hampers such investment - whether of conventional or renewable energy. Politically, the capacity to extend current arrangements, especially the expansion of coal fired power generators to meet the new demand pressures, raises significant political and electoral risks - risks governments of all persuasions are keen to avoid. Even the current Australian Opposition - whose energy narrative is built in part on its perceived climate 'scepticism' and its refusal to support a carbon price, which they label 'a great big new tax' - would be reluctant to place the building of too many new coal fired power stations onto its electoral agenda. Economically, the impact of pricing carbon is yet to be tested, with much investment postponed until the future carbon landscape is clearer. All political sides agree, however, that the maintenance of Australia's energy security relies on significant infrastructure investment, both to address infrastructure decline and inefficiencies and to accommodate more effective design. However, while most agree that such investment is critical, the tenor and shape of this investment remains contested.

Two important elements are often marginalised from prevailing accounts of energy security. First, the potential contribution that renewable energy could make not only to emissions abatement but also to energy security as a whole, including to positioning Australia in a changing global energy market, is often obscured, or directly derided. For example, a renewable energy critic writes that a solar subsidy scheme is not only 'the most extravagant piece of government expenditure' but it is also 'destabilising the commerciality of the electricity supply industry', and, as such, is 'undermining what was arguably the world's most efficient electricity supply industry' (Moran 2011).

In reality, the renewable sector's contribution to energy security occurs in several ways. The sector's core objectives are to diversify and better distribute energy 
sources in response to global warming and to foster and better accommodate innovation and cleaner production as a whole (See Janicke and Lindemann, 2010). This takes place, as we saw, at a time when the electricity distribution infrastructure requires considerable refurbishment to meet increasing energy demand and supply, and to counter transmission losses from inefficient lines. To assist the integration of distributed energy technologies into a 'smarter grid', the Australian Academy of Science propose a very different grid from 'the old model of centralised massive power stations coupled to a monolithic transmission and distribution network' particularly since 'solar, wind, wave and fuel cell power generation facilities will range in size down to the domestic scale' (in AAS, 2010, 20).

Second, reliance on single, or limited, energy sources and over-centralised power generation poses a number of other risks, but particularly the susceptibility to disruption (Li, 2005, p. 2241). Even in a country reliant on a main source of energy, such as Australia, 'system resilience and energy security can be greatly increased with distributed and dispersed power generation ... thereby reducing transmission losses $\ldots$ and [the] vulnerability of having to transmit energy over wide areas' ( $\mathrm{Li}, 2005, \mathrm{p}$. 2241). Diversification is also important since it 'increases flexibility of the energy system and reduces vulnerability to supply constraints or changes in the economic environment', hence becoming 'a key measure of energy security in the long term' (Kinrade, 2007, p. 234, 240). In a climate change environment diversification has an additionally important meaning. As the International Energy Agency observed, renewables can help 'reduce geopolitical security risks by contributing to fuel mix diversification; this is because their 'risks are different from those of fossil fuel supply risks, and they can reduce the variability of generation costs' (IEA, 2007, p. 9). In a rapidly changing global energy marketplace, investment in alternative energy sources 
also represents a distribution of financial risk and a diversification of comparative advantage. Despite promising commercialisation opportunities, 'some of Australia's most promising technologies have been commercialised overseas due to a lack of political interest and investment support here' (ACF/ACTU, 2008, p. 10; see also Huber, 2008).

\subsection{Cost: 'Costing the Earth'}

Cost, a fundamental consideration, forms another influential narrative. New technological developments are generally costly, and renewables, especially on a larger scale, are no exception. The presentation of the renewables' cost scenario varies widely, however. The narratives range from the strident - commitment to a carbon price 'fails to understand that replacing efficient coal generators with high cost windmills would totally destroy the resource base of the Australian economy, returning the nation to some nineteenth century pastoralist past' (Moran, 2010) - to the more measured, which express legitimate concern at the significant costs involved. Often it is simply a case of comparative 'distortions'. For example, a recent comparative cost analysis of conventional energy vis-a-vis solar energy by Frontier Economics was reported as: 'by 2030, to generate 100 per cent of electricity from solar farms at their current costs could cost up to $\$ 64$ bn, compared with $\$ 16$ bn if all electricity were generated from coal' (in Hepworth, 2011c). While the article highlights the 'current cost' comparison, the head of the Australian Clean Energy Council nonetheless observes that the 'frustrating thing about much of the narrative on renewable energy is that the easiest way to marginalise renewable technologies is to compare them with what we have at the moment' (in Lloyd, 2010). 
A useful way of analysing these cost narratives is to consider them against associated knowledge bases that would more adequately contextualise them. These bases, often distinguished by their relative absence in the debate, include subsidies to the conventional energy sector, the prospects and costs of clean coal alternatives, and the issue of rising domestic electricity prices.

\subsubsection{Subsidies}

One of the factors that contributes to Australia's relatively cheap electricity prices is the subsidisation of the fossil fuel sector. As Riedy (2007, p. iii) points out, Australia provides 'substantial financial support for the production and use of fossil fuels, through direct payments, favourable tax treatment and other actions'; this keeps 'the cost of fossil fuel energy artificially low', making it 'harder for renewable energy to compete'. This compares to support for renewable technologies which (in 2007) stood at 4 per cent of identified subsidies relative to the over ' $96 \%$ of the identified energy and transport subsidies' provided to fossil fuel production and consumption (Riedy, 2007, p. iii). Despite renewable energy subsidies often portrayed negatively as 'picking winners', the subsidy profile instead reveals 'an uneven playing field for renewable energy making it much more difficult to respond to climate change in the energy and transport sectors' (Riedy, 2007, p. iii). While the investment environment has changed since 2007, especially with the introduction of an expanded renewable energy target in 2009 and a range of solar rebate schemes, the fossil fuel subsidy profile remains in place. Instead extensive criticism has been directed to the much smaller scale renewable energy subsidies, such as solar rebate and feed-in-tariff (FIT) 
schemes $^{2}$ - even as their policy designs, and hence their operation, have contained significant flaws. ${ }^{3}$ A comparison with development costs of alternatives such as clean coal and sequestration technologies also helps contextualise these cost narratives.

\subsubsection{Clean Coal and Sequestration Technologies}

The clean coal (including carbon capture and storage) alternative is widely promoted as the win-win climate change solution (see Backstrand et al, 2011; Buhr and

Hansson, 2011). On the one hand, it retains coal's primacy in the Australian economy and as its major electricity source; on the other, by proposing to 'clean' it, Australian coal helps address the climate problem. As elsewhere, clean coal technologies generate polarised views in Australia. Supporters point to their enormous potential, especially in the face of the world's continued reliance on coal fired power generation. Advocates of carbon capture and storage highlight the wealth of experience the oil industry provides in injection technologies, as well as the existence of many depleted reservoirs and saline aquifers potentially suitable as storage sites (see Bickle, 2009, p. 816). Detractors often caste carbon capture and storage as a 'Faustian bargain' akin to nuclear; as 'a double edged sword' that acts to delay research on 'more durable measures' (Spreng et al., 2007, p. 853). These views highlight the politically charged discursive framing, of CCS development. For some,

2. The different state-based solar Feed-in-Tariff schemes pay domestic consumers a price for the electricity they feed back into the electricity grid through their domestic solar pv systems. This premium is calculated either in a net or gross form.

3. The MRET and FITs experience illustrate this (see Buckman and Diesendorf, 2010). The expanded MRET scheme, as originally conceived, quickly experienced a number of problems. It was first undermined when domestic solar panels and solar hot water were awarded RECs and included in the target. This was largely a political move: a response to the withdrawal of the $\$ 8000$ solar rebate which became 'too successful' with its 'over-subscription' going considerably over-budget. This resulted in the flooding of the renewable energy market with RECs, collapsing their price. Since the RECs were a main source of renewable energy investment, the upshot was that smaller domestic solar units were crowding out larger renewable ventures like wind farms, hydro and biogas, rendering the latter commercially nonviable. This design fault has since been (partially) addressed. 
'clean' coal technologies represent 'an easy way out of having to make more difficult and sustainable choices' (Spreng et al., 2007, p. 853). Indeed, having an alternative such as CCS is viewed as critically important to the coal narrative: '[i]n theory, research could continue indefinitely without scaled commercialisation, as long as “clean coal" remains a credible objective' (Palmer, 2009, p. 45). Furthermore, these technologies signal business and government commitment to sustainable energy solutions through an agenda that, in effect, retains the energy status quo.

Australia, like other coal reliant economies, has committed substantial funds to research and development for a range of clean coal technologies. ${ }^{4}$ This is despite the feasibility concerns that continue to afflict them. While some projects, generally small scale, have proceeded to promising demonstration stage, there remains limited clarity on how long it would take to assure their workability and then to develop them to commercial scale. Current estimations are between 10 - 20 years. Recent Australian efforts to advance these technologies have proved disappointing. The Queensland Government, Australia's largest coal-producing state, announced the closure of its high profile carbon capture site, ZeroGen, at the end of 2010, along with the abandonment of its planned $\$ 4.3$ billion clean coal power station in central Queensland (Lion, 2010). One of the primary objectives of ZeroGen was to make Australia a leader in the development of clean coal technologies, with the government investing over $\$ 150$ million dollars in a project that was expected to be fully operational by 2020. Instead, a review that cast serious doubts on the project's feasibility, finding its prospects 'speculative' and financially unviable, prompted the recent decision to discontinue it.

4. However, some funding was withdrawn in January 2011, as a cost saving measure to fund costly reconstruction work after widespread flood damage in Australia. 
While views of the clean coal alternative differ, there is little disagreement about its costliness. These costs include continued research and development, the funding of demonstration projects, significant retrofitting expenditure, the establishment of costly new generation coal fired utilities and the development of associated infrastructure (Palmer, 2009). Some studies have estimated that capture and storage technologies for US electricity production 'could add between 50-100 per cent increase in power costs' (Bickle, 2009, p. 815). Viewed this way, renewables would become much more cost competitive with (cleaned) coal.

\subsubsection{Pricing electricity and infrastructure}

These cost considerations are in any case exacerbated by rapidly rising domestic electricity prices - price rises, however, that offer discursive opportunities to steer already sensitive cost narratives in particular directions. Long renowned for their affordability, domestic electricity prices have risen appreciably over the past two years in Australia, and are projected to rise even more steeply in 2011-13. These rises can be attributed to increased demand, changing energy consumption patterns, population increases, historical shortfalls in electricity infrastructure investment and the impact of poorly designed renewable energy policies (see Dusevic and Hepworth, 2011a; NESA, 2009). Uncertainty around the introduction of a carbon price also contributes to price volatility. Australia's major renewable energy policies, in particular the MRET and the state-based domestic solar Feed in Tariff schemes, are heavily targeted in these price rises. The poor design of some of these schemes which even strong promoters of renewable energy such as the Australian Greens and many in the renewable energy sector itself, have pointed out are poorly conceived has contributed to some price rise (see Milne, 2011; Buckman and Diesendorf, 2010). 
The recent experience with NSW's FIT scheme, where a high premium rendered the scheme very costly, provided considerable fodder for long standing opponents, and helped discursively reinforce the link between renewable energy developments and rising electricity prices. The existence of some link between renewable policies and electricity price rises, has been seized upon in the construction of narratives - 'the energy sector wilts under solar stress' (Moran 2011) - that seek to implicate renewables, more so than other relevant factors, in these price increases. While it is difficult to accurately determine the price impact of renewable policies with estimates ranging from the minimal (see CEC, 2010) to the significant (see Hepworth, 2011b) - more accurate but often more complex explanations can be less appealing than straightforward causal ones, hence creating narrative opportunities to embed the perception of a stronger relationship between renewable energy policies and cost impacts than may be the case. The effectiveness of such a narrative link has also driven a political propensity to withdraw problematic renewable energy policies rather than successfully remodel them. This is despite some success in approximating grid parity in some areas (see Cubby et al, 2011).

This 'promote-withdraw' policy dynamic - political promotion on the one hand but poor policy design and ultimate policy withdrawal on the other - has dogged many renewable energy schemes in the last few years. The 'success' of these schemes has had the effect of creating a 'boom-bust' cycle, particularly for domestic solar schemes, that undermines industry and investment confidence. ${ }^{5}$ These boom-busts not only impact on industry confidence but also on job growth in the renewables sector.

5. The 'success' paradox is interesting. One of the factors that has prompted a review and/or withdrawal of a number of rebate schemes was the charge that they were 'too successful' that is, too many consumers installed solar panels. The policy intent of most of these schemes was to use the price signal to make renewable energy cost competitive, hence activating behavioural change, both for consumers and industry. As a solar industry analyst commented, the fundamental objective was 'to drive the cost of solar to what we call grid parity ... where 


\subsection{Employment: 'Jobs Carnage'}

The issue of jobs rivals that of cost in its public sensitivities. Whether referring to job losses or job creation, employment has long been a powerful discourse and is often centre stage in proposed industry developments. Indeed, as Seligman points out: 'when people are against something expensive, then it will damage the economy and when they are for it, it will create jobs' (Seligman, 2010, p. 44). The employment impacts of sectoral restructuring are hence central to renewable energy's profile, particularly in a regional resource economy such as Australia. As we saw, coal is central to the Australian economy and much coal mining and electricity generation work is regionalised, with extensive spill over effects on local communities. These regionalised employment arrangements hence complicate the impacts of ecological restructuring on the network of communities that rely on these jobs (see Pearce and Stillwell, 2008, pp. 132-35). Nor is the proposal to re-train workers and re-distribute employment opportunities in new renewable energy industries as straightforward as it may first appear (Pearce and Stillwell, 2008, p. 126). Some precedents do exist, however, particularly the highly charged restructuring effort of the 1980s which ushered in substantial transformation of Australia's manufacturing sector (Conley, 2010). Lessons from this period highlight the importance of effective management, planning and policy frameworks for steering contentious structural adjustments over lengthy and turbulent time periods.

the investment cost of the technology plus the cost of financing is the same as or less than what you can buy electricity from the coal-fired grid for' (ABC, 2010). While objections to the rebates also raised equity concerns - as currently designed the rebates advantaged wealthier consumers who could better afford the initial costs, this can overlook the policy's broad intent: to act as a bridge 'between where we are and where we need to be so that [solar] becomes a mainstream application that [ultimately] requires no government support' (ibid). European countries with various feed-in-tariff solar rebate schemes are currently providing considerable evidence of this occurring (see Wilson, 2011). 
The structural adjustment demands of a clean energy future hence create widespread employment and regional uncertainty. This uncertainty is reinforced by the difficulty of accurately predicting the movement of 'green' jobs and the broader impacts on local communities. Definitions of what constitutes a 'green job' can vary widely and green job figures do not always detail regional implications and the impacts of transitional arrangements (see Hatfield-Dodds et al., 2007; Pearce and Stilwell, 2009). These uncertainties create a discursive opening in which a narrative of 'jobs carnage' can prosper. The chief executive of the Mineral Council of Australia, for example, in response to the proposed emissions trading scheme in 2009 (since withdrawn), viewed energy sector restructuring as 'jobs carnage'. He claimed that the government's then climate plan would 'shed 23,510 jobs in the minerals sector by 2020 and more than 66,000 by 2030' (Hooke, 2009). In addition, no state or mining sector 'will be spared' and 'the impact on regional Australia will be severe'.

'Jobs carnage' narratives, which tap into understandable employment insecurities, are hence formidable competitors with other narratives and knowledge bases which tell more optimistic stories. A CSIRO Report (2007) titled Growing the Green Collar Economy projects that 'a rapid transition to sustainability would have little or no impact on national employment, with projected increases in employment of 2.5 to 3.3 million jobs over the next two decades' (Hatfield-Dodds et al., 2007, p. 1). They envision that 'employment in sectors with high potential environmental impacts will also grow strongly, with projected increases of more than 10 per cent over ten years'; this would translate to an additional 230,000 to 340,000 new jobs in a range of related sectors with employment in some sectors, such as construction and transport 'projected to grow significantly faster than the national average' (HatfieldDodds et al., 2007, p. 1). A report on Australia's projected Green Gold Rush posits 
similarly scenarios (ACF and ACTU, 2008), as does the more recent Zero Emissions Australia report (Zero Emissions Australia, 2010). The findings from these reports are reinforced by the proposal that renewable energy production in fact requires more jobs than conventional production, including in regional areas - one of the reasons for its costliness (Lovegrove, 2008).

Broaching issues that are of fundamental importance to people's livelihoods, jobs discourses are often very strident and emotive, and hence highly polarised. A narrative contest thus emerges between the more positive or more negative projections. The reality is likely to be that any substantial sectoral restructuring will impose significant upheaval - with some bearing the brunt of this upheaval more so than others. But then so too could climate change impose significant upheaval to regional and employment futures particularly the impact of more frequent weather extremes on the agricultural and mining sectors. ${ }^{6}$ This is another narrative, however, more noted for its relative absence than presence in the debate, even as the restructuring impacts of climate change and climate change adaptation are generally agreed to be onerous and extensive (see Garnaut, 2008; Christoff, 2010; Palutikof, 2010).

\section{Conclusion}

Feasibility, security, cost and employment are central elements of a country's energy profile and hence critical considerations in the design of its energy plans. With increasing energy demand, changing energy consumption patterns, infrastructure

6. Australia recently had a taste of what an increased frequency of extreme weather events could mean. In late 2010 to early 2011 extreme flooding and cyclones devastated almost half of the huge Australian continent, causing a very large damages bill in the billions, crippling the agricultural sector (with some industries not expected to recover) and, aside from extensive damage to homes and communities, creating costly delays and extensive infrastructure damage to mining industries. 
decline and the threats posed by climate change, Australia, as elsewhere, confronts the 'central question' of 'how to design a new energy policy with security of supply and climate change at the core' (Helm, 2005, p. 16). Australia's fossil fuel abundance and its energy intensive economy complicate the tenor of its response to these challenges. As we saw, Australia's economic success is underpinned by its minerals resource wealth, and governments rely on the economic and employment benefits that the mining sector brings. This has ensured an influential role for a sector - including energy intensive industries that find Australia's relatively cheap electricity an investment incentive - keen to protect existing energy arrangements and guide the shape of any unavoidable change. This sector, whose mining arm is currently the beneficiary of very profitable mining booms in Australia, is thus able to exert considerable influence on energy planning. This was most recently demonstrated by the generous compensation its trade exposed energy intensive industries and coal fired electricity generators were able to win during the recent 2011 carbon tax negotiations, and its success in considerably diluting the terms of a mining resource rent tax.

Against this background of highly rewarding existing energy arrangements, the energy futures stakes are high. The capacity to structure and tell the best story about these energy futures goes a long way towards also being able to shape them. As we saw, the narratives discussed in the paper achieve their potency in direct relationship to the unease they invoke about the capacity of an advanced industrial society to continue fulfilling its core functions. Rather than dismissing or deriding renewable energy altogether, these narratives instead caste doubt on, and creates reasonable uncertainty about, the capacity of a country to continue meeting its socioeconomic obligations. The feasibility and security narratives reinforce the reasonableness of citizen concerns about capacity to maintain given lifestyles, and of 
taken-for-granted socio-economic conditions. Cost of living factors and misgivings about future employment fuel insecurities about the shape and impacts of proposed energy transformations - even in the face of evidence to the contrary.

Overall, the narratives about renewable energy discussed in this paper derive their potency in two main ways. First, they are structured around reasonableness and 'common sense' concerns - elements important to discursive success. As RogerHayden et al $(2011,135)$ observe, a discourse is strengthened by its capacity to 'naturalise' its meanings; that is, when it 'succeeds in making its own rules/systems/beliefs appear to be the "natural" ones', or, in short, when particular narrative positions advanced appear to derive 'naturally' from a social consensus about values and socio-economic priorities. Second, the effectiveness of our identified narratives was determined as much by contextualising information absent from the energy conversation as present. The overall impact is often the intended one: confusion and uncertainty about the contribution renewable energy could in actuality make to a sustainable energy future in Australia, and hence to helping address the climate problem.

\section{References}

Altieri, M. 2009. The Ecological Impacts of Large-Scale Agrofuel Monoculture Production Systems in the Americas. Bulletin of Science, Technology and Society 29, 236-244.

Australian Academy of Science. 2010. Australia's Renewable Energy Future: December 2009. Co-editors: Dopita, Michael and Robert Williamson. Canberra: Australian Academy of Science. 
Australian Broadcasting Corporation (ABC). 2010. Rich reap benefits of solar rooftop subsidies. AM. 11 November. Available at:

http://www.abc.net.au/am/content/2010/s3063136.htm (accessed November, 2010).

Australian Broadcasting Corporation (ABC). 2011. Four Corners: The Gas Rush.

Available at:

http://www.abc.net.au/4corners/content/2011/s3141787.htm, broadcast 22 February.

Australian Conservation Foundation (ACF) and Australian Council of Trade Unions (ACTU). 2008. Green Gold Rush: How ambitious environmental policy can make Australia a leader in the global race for green jobs. Available at: http://www.acfonline.org.au/uploads/res/Green_Gold_Rush_final.pdf.

Australian Government. Department of Resources, Energy and Tourism. 2009. National Energy Security Assessment. Canberra: Commonwealth of Australia. Available at: http://www.abc.net.au/science/articles/2010/12/02/3081889.htm (accessed January 2011).

Backstrand, K., Meodowcroft, J., Oppenheimer, M., 2011. The politics and policy of carbon capture and storage: Framing an emergent technology. Global Environmental Change 21, $275-281$.

Beyond Zero Emissions. 2010. Zero Carbon Australia Stationary Energy Plan. University of Melbourne: Energy Research Unit. July.

Bickle, M. 2009. Geological Carbon Storage. Nature GeoScience 2, 815-818.

Brait, P., Ewbank, L. 2010. A Renewable Reality: Don't let politics get in the way. Beyond Zero Emissions. 22 June. Available at: http://beyondzeroemissions.org/media/newswire/renewable-reality-dont-let-politicsget-way-100622 (accessed January 2011).

Buckman, G., Diesendorf, M. 2009. The Future of Renewable Electricity in Australia. The Australian National University, Crawford School of Economics and Government. Research Report No. 30. May 15.

Buckman, G., Diesendorf, M. 2010. Design limitations in Australian renewable electricity policies. Energy Policy 38: 3365-3376.

Buhr, K., Hansson, A., 2011. Capturing the stories of corporations: A comparison of media debates on carbon capture and storage in Norway and Sweden. Global Environmental Change 21, $336-345$.

Christoff, C. 2010. Touching the void: The Garnaut Review in the chasm between climate science, economics and politics. Global Environmental Change 20, 214-217.

Clean Energy Council (CEC) 2009. Clean Energy Australia 2009. Clean Energy Council. Available at: www.cleanenergycouncil.org.au (accessed July 2010). 
Clean Energy Council (CEC). 2010. Networks, not solar, driving rising electricity costs CEC. 7 October. Available at: http://www.industrysearch.com.au/News/Networksnot-solar-driving-rising-electricity-cost-CEC-47184 (accessed November 2010).

Conley, T. 2010. Globalisation, Australian Political Economy and Global Crisis. In Curran, G. van Acker, E. (Eds). Business and the Politics of Globalisation: After the Global Financial Crisis. Pearson, Sydney.

Cubby, B., Robins, B., Lahoud, M., 2011. Solar energy cost hits par with coal fuel. Sydney Morning Herald. 18 August.

Curran, G. 2009. Ecological Modernisation and Climate Change in Australia. Environmental Politics 18 (2), 201-217.

Diesendorf, M. 2010. The Base Load Fallacy. In Energy Science. Briefing Paper 16. March. Available at: http://www.energyscience.org.au/ (accessed July 2010).

Dryzek, J. 2005. The Politics of the Earth: Environmental Discourses. Oxford University Press, Oxford.

Dusevic, T., Hepworth, A. 2011. The power shocks to come. The Australian. 29 January.

Energy Matters. 2009. Survey: Australians Favour Renewable Energy Over Nuclear. Available at: http://www.energymatters.com.au/index.php?main_page=news_article\&article_id=69 $\underline{9}$ (accessed August 2010).

Ferguson, M. 2010. Energy prices will keep rising. The Australian. 22 March.

Fischer, F. 2003. Reframing Public Policy: Discursive Politics and Deliberative Practices. Oxford University Press, Oxford.

Flyvbjerg B, 1998. Rationality and Power. University of Chicago Press, Chicago.

Foucault, M. 1980. Power/Knowledge. Harvester Press, London.

Garnaut, R. 2008. The Garnaut Climate Change Review: Final Report. Available at: http://www.garnautreview.org.au/pdf/Garnaut_prelims.pdf

Haggett C. 2008. Over the sea and far away? Journal of Environmental Policy \& Planning 10 (3), 289-306.

Hajer, M. 1993. Discourse coalitions and the institutionalization of practice: the case of acid rain in Great Britain. In Fischer, F., Forester, J. The Argumentative Turn in Policy Analysis and Planning. Duke University Press, Durham, pp. 43-76.

Hajer, M. 1995. The Politics of Environmental Discourse: Ecological Modernisation and the Policy Process. Oxford University Press, New York. 
Hatfield-Dodds, S., Turner, G., Schandl, H., Tanjua, D. 2008. Growing the Green Collar Economy: Skills and labour challenges in reducing our greenhouse emissions and national environmental footprint. CSIRO: Report to the Dusseldorp Skills Forum. June. Available at: http://www.acfonline.org.au/uploads/res/CSIROGreenJobsFinalReport_080625.pdf.

Helm, D. 2008. Climate change policy: why has so little been achieved? Oxford Review of Economic Policy 24 (2), 211-238.

Hepworth, A. 2011a. Burn out for populist power plays. The Australian. 7 February.

Hepworth, A. 2011b. Electricity prices to increase yet again. The Australian. 5 February.

Hepworth, A. 2011c. Danger in target for renewable energy. The Australian. 20 July.

Hindmarsh, R., Matthews, C. 2008. Deliberative speak at the turbine face. Journal of Environmental Policy and Planning 10 (3): 217-32.

Hooke, M. 2009. Carbon plan will cause jobs carnage. The Australian. 22 May.

Huber, J. 2008. Pioneer countries and the global diffusion of environmental innovations: theses from the viewpoint of ecological modernisation theory. Global Environmental Change 18, 360-367.

International Energy Agency (IEA). 2007. Contribution of Renewables to Energy Security. Available at: http://www.iea.org/papers/2007/so_contribution.pdf

International Energy Agency (IEA). 2009. World Energy Outlook 2009. Paris: OECD/IEA.

Jacques, P., Dunlap, R., Freeman, M. 2008. 'The organisation of denial: Conservative think tanks and environmental scepticism'. Environmental Politics 17 (3), 349-385.

Janicke, M., Lindemann, S. 2010. Governing Environmental Innovations. Environmental Politics 19 (1), 127-141.

Kinrade, P. 2007. Toward a sustainable energy future in Australia. Futures 39 (2-3), 230252.

Ladenburg J. 2009. Stated public preferences for on-land and offshore wind power generation. Wind Energy 12, 171-81.

Ladenburg, J. 2008. Attitudes towards on-land and offshore wind power development in Denmark. Renewable Energy 33, 111-8.

Li, X. 2005. Diversification and localizaiton of energy systems for sustainable development and energy security. Energy Policy 33 (17), 2237-2243.

Lion, P. State Government drops ZeroGen project after taxpayers pump \$150 million into the plan. 2010. Sunday Mail. 19 December. 
Lloyd, G. 2010. The Great Wind Rush. The Australian. 27 November.

Lovegrove, K. 2009. Solar thermal concentrators: Capturing the sun for large scale power generation and energy export. Australian Academy of Science. Public Lecture Series: Australia's Renewable Energy Future. 7 April. Available at: http://science.org.au/events/publiclectures/re/lovegrove.html (accessed March 2010).

Mills, D. 2010. Busting the baseload power myth. ABC Science. 2 December.

Milne, C. The Australian Greens. 2011. Feed In Laws. Media Release 15 February. Available at: http://christine-milne.greensmps.org.au/taxonomy/term/246/all (accessed February 2011).

Minerals Council of Australia (MCA). 2009. COAG Working Group on Climate Change and Water: Discussion Paper. Available at: http://www.minerals.org.au/_ data/assets/pdf file/0019/33544/RET_EITESubmission_Feb09.pdf (accessed August 2010).

Moran, A., 2011. Energy sector wilts under solar stress. The Australian. 21 January.

Moran, A. 2010. DCC briefing: a farrago of spin, obfuscation and exaggeration. In The Drum Unleashed. Australian Broadcasting Corporation. 4 November. Available at: http://www.abc.net.au/unleashed/40764.html (accessed December 2010).

Newspoll and Clean Energy Council of Australia (CEC). 2010. Energy Sources Report: 9 May 2010. Available at:

http://www.cleanenergycouncil.org.au/cec/resourcecentre/newspoll.html (accessed August 2010).

Newspoll and Clean Energy Council of Australia (CEC). 2009. Energy Studies Report: 1 December 2009. Available at: http://www.cleanenergycouncil.org.au/cec/resourcecentre/newspoll.html (accessed August 2010).

Palmer, G. 2009. Out of sight or out of time: the future of carbon capture. Dissent (Spring), 43-48.

Palutikof, J. 2010. The view from the front line: Adapting to climate change. Global Environmental Change. 20, 218-219.

Parker, L., Blodgett, J. 2008. Greenhouse gas emissions: perspectives on the top 20 emitters and developed versus developing nations. Congressional Research Service Report to Congress. November 2008.

Pearce, A., Stillwell, F. 2008. 'Green-Collar' Jobs: Employment impacts of climate change policies. Journal of Australian Political Economy 62, 120-138. 
Pettenger, M. 2007. Introduction: Power, Knowledge and the Social Construction of Climate Change. In Pettenger, M. (Ed). The Social Construction of Climate Change: Power, Knowledge, Norms, Discourses. Ashgate, Aldershot, pp. 1-19.

Pimentel, D., Marklein, A., Toth, M., Karpoff, M., Paul, G., McCormack, R., Kyriazis, J., Krueger, T. 2009. Food versus Biofuels: Environmental and economic costs. Human Ecology 37, 1-12.

Riedy, C. 2007. Energy and Transport Subsidies in Australia. A 2007 Update. Final Report for Greenpeace Australia Pacific. University of Technology Sydney: Institute for Sustainable Futures.

Rogers-Hayden, R., Hatton, F., Lorenzoni, I., 2011. 'Energy security' and 'climate change': Constructing UK energy discursive realities. Global Environmental Change $21,134-142$.

Rutovitz, J., Dunstan, C. 2009, 'Meeting NSW electricity needs in a carbon constrained world: lowering costs and emissions with distributed energy', [prepared for Project 4 of the CSIRO Intelligent Grid Research Program], Institute for Sustainable Futures, Sydney: University of Technology Sydney.

Scrase, J., Ockwell, D., 2010. The role of discourse and linguistic framing effects in sustaining high carbon energy policy - An accessible introduction. Energy Policy 38, $2225-2233$.

Seligman, P. 2010. Australian Sustainable Energy - by the numbers. University of Melbourne, Melbourne Energy Institute.

Spreng, D., Marland, G., Weinberg, A. 2007. CO2 capture and storage: Another Faustian Bargain? Energy Policy 35 (2), 850-854.

Stevenson, R. 2009. Discourse, power, and energy conflicts: understanding Welsh renewable energy planning policy, Environment and Planning C: Government and Policy 27, 512-526.

Toke, D. (Ed). 2011. Special Section on Offshore Wind Power Planning, Economics and Environment. Energy Policy 39 (2).

Toke, D. 2005. Explaining wind power planning outcomes. Energy Policy 33, 1527-39.

United States Energy Information Administration (EIA). 2010. Australia's Energy Profile. Available at: http://www.eia.doe.gov/countries/cab.cfm?fips=AS (accessed October, 2010).

Wilson, P. 2011. Sun setting on European solar subsidies. The Australian. 5 March.

World Nuclear Association. 2011. Australia's Uranium. Available at: http://www.world-nuclear.org/info/inf48.html (accessed February 2011). 
Wright, J. 2009. The contribution of renewables in Australia's future energy mix. Australian Academy of Science. Public Lecture Series: Australia's Renewable Energy Future. 4 August. Available at:

http://science.org.au/events/publiclectures/re/lovegrove.html (accessed 4 March 2010). 